\title{
Direct repair of the aortic root and arch in acute type A dissection: Is outcome related to technique, patient selection, or experience?
}

\author{
Leonard N. Girardi, MD
}

From the Department of Cardiothoracic Surgery, Weill Cornell Medicine, New York, NY

Disclosures: Author has nothing to disclose with regard to commercial support.

Received for publication Dec 17, 2017; accepted for publication Dec 27, 2017; available ahead of print Jan 25, 2018.

Address for reprints: Leonard N. Girardi, MD, 525 E 68th St, M-404, New York, NY 10065 (E-mail: lngirard@ med.cornell.edu)

J Thorac Cardiovasc Surg 2018;155:1355-6

$0022-5223 / \$ 36.00$

Copyright (C) 2018 by The American Association for Thoracic Surgery

https://doi.org/10.1016/j.jtcvs.2017.12.087

In this issue of the Journal, Yang and colleagues ${ }^{1}$ report their experience with "direct repair" of acute type A aortic dissection (ATAAD) without the use of biological glues or prosthetic reinforcement of the dissected aortic wall. In a total cohort of 94 patients with ATAAD, a highly selected group of 45 patients were treated by a single, experienced aortic surgeon with "root repair." Patients with intimal tears at the root, connective tissue disorders, root diameter greater than $4 \mathrm{~cm}$ in patients aged less than 65 years, and root diameter less than $4.5 \mathrm{~cm}$ in patients aged more than 65 years were treated with root replacement $(n=39)$. The repair technique consisted of a circumferential reapproximation of the walls of the dissected aorta at the sinotubular junction and arch with 5-0 polypropylene suture followed by a similar anastomosis to a Dacron graft. The authors did not invert the adventitia to further reinforce the suture line. ${ }^{2}$ The operative mortality for this cohort was $7 \%$, and over a mean follow-up period of 22 months, the repair cohort was free of pseudoaneurysm formation, recurrent or residual root dissection, major changes in root diameter, or significant aortic insufficiency. Overall survival after repair was $85 \%$ at 4 years, significantly better than for those undergoing root replacement $(57 \%)$. Is this technique a substantial improvement over more traditional methods of repair, and will it reduce the risk of late root and arch complications needing riskier reoperations?

A closer look at the short-term and long-term outcomes of surgery for ATAAD is warranted to contextualize the results reported in this editorial. Operative mortality continues in the $15 \%$ to $20 \%$ range in large registries using a variety of surgical techniques. ${ }^{3,4}$ In centers of excellence, where teams perform these high-risk procedures rather than a single surgeon, mortality rarely falls below $10 \%$. $^{5,6}$ Once the patient gets through the initial risk of the acute event, follow-up imaging is crucial to detect late complications. Approximately $27 \%$ of patients will develop significant root disease after surgery for ATAAD. Ten percent of

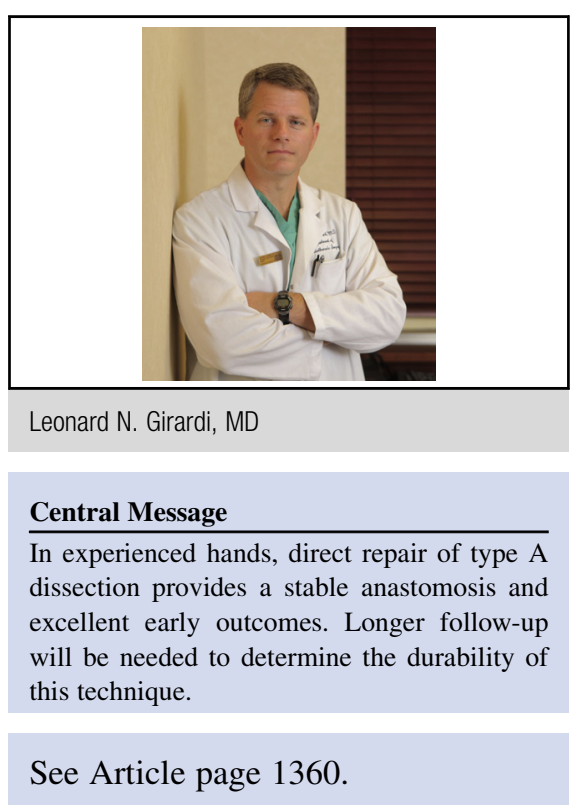

patients will ultimately require root reoperation, with half of those procedures being secondary to the development of late anastomotic pseudoaneurysms. ${ }^{7}$ Downstream aortic complications are also of concern. The incidence of these events was not influenced by the use of the direct suture technique in the arch. More than half of the 45 patients in whom this technique was used experienced distal false lumen thrombosis. One patient required open repair of a descending aneurysm. An increase in descending aortic diameter was also seen in a few patients having follow-up imaging up to 4 years. More late imaging will be necessary to see how this ultimately plays out.

The direct repair technique may turn out to be an improvement. Biological glues have deservedly come under intense scrutiny and have been shown to lead to substantial late tissue necrosis. ${ }^{8,9}$ When Teflon felt is used, it sticks to every surrounding structure, so its elimination would be a blessing for those having to perform these complicated reoperations (if you try to tell me felt doesn't bother you during a reop...c'mon!). However, the mean follow-up time reported in this series is quite limited and substantially less than the 5.4 years between the index procedure and the reoperation reported by other experienced surgeons. ${ }^{7}$ The elimination of adjuncts to secure hemostasis may result in improved early and late outcomes. As always, however, 
patient selection (not too large a root or arch, no connective tissue disease), preoperative comorbidities (shock, tamponade, malperfusion, previous open surgery), ${ }^{10}$ and greater surgeon experience are likely to be the most influential factors improving the expected outcomes for patients in need of surgery for ATAAD.

\section{References}

1. Yang B, Malik A, Waidley V, Xiaoting Wu, Norton EL, Williams DM, et al. Short-term outcomes of a simple and effective approach to aortic root and arch repair in acute type A aortic dissection. J Thorac Cardiovasc Surg. 2018;155: 1360-70.

2. Oda T, Minatoya K, Sasaki H, Tanaka H, Seike Y, Itonaga T, et al. Adventitial inversion technique for type A aortic dissection distal anastomosis. J Thorac Cardiovasc Surg. 2016;151:1340-5.

3. Trimarchi S, Nienaber CA, Rampoldi V, Myrmel T, Suzuki T, Mehta RH, et al. Contemporary results of surgery in acute type A aortic dissection: The International Registry of Acute Aortic Dissection experience. J Thorac Cardiovasc Surg. 2005;129:112-22.

4. Conzelmann LO, Weigang E, Mehlhorn U, Abugameh A, Hoffmann I, Blettner M, et al; GERAADA Investigators. Mortality in patients with acute aortic dissection type A: analysis of pre- and intraoperative risk factors from the German Registry for Acute Aortic Dissection Type A (GERAADA). Eur J Cardiothorac Surg. 2016;49:e44-52.

5. Rylski B, Milewski RK, Bavaria JE, Vallabhajosyula P, Moser W, Szeto WY, et al. Long-term results of aggressive hemiarch replacement in 534 patients with type A aortic dissection. J Thorac Cardiovasc Surg. 2014;148:2981-5

6. Leshnower BG, Myung RJ, McPherson L, Chen EP. Midterm results of David V valve-sparing aortic root replacement in acute type A dissection. Ann Thorac Surg. 2015;99:795-801.

7. Rylski B, Beyersdorf F, Blanke P, Boos A, Hoffmann I, Dashkevich A, et al. Supracoronary ascending aortic replacement in patients with acute aortic dissection type A: what happens to the aortic root in the long run? J Thorac Cardiovasc Surg. 2013;146:285-90.

8. Karck M. The glue crisis in surgery of acute aortic dissection type A is ongoing. Eur J Cardiothorac Surg. 2012;41:E36-7.

9. Suzuki S, Imoto K, Uchida K, Takanashi Y. Aortic root necrosis after surgical treatment using gelatin-resorcinol-formaldehyde (GRF) glue in patients with acute type A aortic dissection. Ann Thorac Cardiovasc Surg. 2006; $12: 333-40$.

10. Rampoldi V, Trimarchi S, Eagle KA, Nienaber CA, Oh JK, Bossone E, et al. Simple risk models to predict surgical mortality in acute type A aortic dissection: the International Registry of Acute Aortic Dissection score. Ann Thorac Surg. 2007; $83: 55-61$. 